\title{
Thermoprotection by glycine betaine and choline
}

\author{
Teresa Caldas, ${ }^{1}$ Nathalie Demont-Caulet, ${ }^{1}$ Alexandre Ghazi ${ }^{2}$ \\ and Gilbert Richarme ${ }^{1}$
}

Author for correspondence: Gilbert Richarme. Tel: +331442750 98. Fax: +33144273580. e-mail: richarme@ccr.jussieu.fr

\footnotetext{
1 Biochimie génétique, Institut Jacques Monod, Université Paris 7, 2 place Jussieu, 75251 Paris Cedex 05, France

2 Laboratoire des Biomembranes, ERS571/CNRS, Université Paris Sud, bat. 430 , 91405 Orsay, France
}

\begin{abstract}
Glycine betaine is mostly known as an osmoprotectant. It is involved in the osmotic adaptation of eukaryotic and bacterial cells, and accumulates up to $1 \mathrm{M}$ inside cells subjected to an osmotic upshock. Since, like other osmolytes, it can act as a protein stabilizer, its thermoprotectant properties were investigated. In vitro, like protein chaperones such as DnaK, glycine betaine and choline protect citrate synthase against thermodenaturation, and stimulate its renaturation after urea denaturation. In vivo, the internal concentration of glycine betaine is neither increased nor decreased after heat shock (this contrasts with a massive increase after osmotic upshock). However, even in exponential-phase bacteria grown in usual minimal salts media, the internal glycine betaine concentration attains levels (around $50 \mathrm{mM}$ ) which can protect proteins against thermodenaturation in vitro. Furthermore, glycine betaine and choline restore the viability of a dnaK deletion mutant at $42{ }^{\circ} \mathrm{C}$, suggesting that glycine betaine not only acts as a thermoprotectant in vitro, but also acts as a thermoprotectant for Escherichia coli cells in vivo.
\end{abstract}

Keywords: glycine betaine, choline, osmoprotectant, thermoprotectant, heat-shock protein DnaK

\section{INTRODUCTION}

The osmoprotectant glycine betaine is accumulated in Escherichia coli cells to molar concentrations at high osmolarity, usually by uptake from the extracellular environment, although certain strains can also synthesize betaine from choline (Conska \& Epstein, 1996). The addition of low concentrations of glycine betaine to the growth medium (e.g. $1 \mathrm{mM}$ ) raises the upper limit of external osmolarity at which growth occurs (Chambers \& Cunin, 1985), and increases the growth rate of osmotically stressed $E$. coli and Salmonella typhimurium (Perroud \& Le Rudelier, 1985). Two osmotically regulated permeases, ProP (Milner et al., 1988) and ProU (Stirling et al., 1989), mediate uptake of glycine betaine in E. coli (Gowrishankar, 1986; Stirling et al., 1989). E. coli can also synthesize glycine betaine from exogenous choline (Strom et al., 1986), which is accumulated by the Bet T and ProU systems, and is converted to betaine by choline dehydrogenase and betainealdehyde dehydrogenase, the bet $A$ and bet $B$ gene products, respectively. The protective effects of glycine betaine against salt stress can also be dem- onstrated in vitro: betaine can restore the activity of malate dehydrogenase inhibited by $0.3 \mathrm{M} \mathrm{NaCl}$ (Pollard \& Wyn Jones, 1979). Furthermore, betaine and other trimethylamines display more general stabilizing effects on macromolecules, increasing their melting temperature, and counteracting the perturbation of enzyme structure and function by urea (Hand \& Somero, 1982; Yancey \& Somero, 1979; Yancey et al., 1982). During heat shock, cellular proteins are prone to aggregation. Cells produce specific proteins such as the major chaperones GroEL/GroES, DnaK/DnaJ/GrpE and the proteases Lon and Clp, which help to cope with the accumulation of heat-denatured proteins (Georgopoulos et al., 1994; Hendrick \& Hartl, 1993). Chaperones interact with heat-denatured proteins, prevent their aggregation, and catalyse their renaturation (Georgopoulos et al., 1994; Hendrick \& Hartl, 1993). In the present study, we show that glycine betaine and choline, at relatively low concentrations, protect citrate synthase and $\beta$-galactosidase against thermodenaturation in vitro, and stimulate citrate synthase renaturation after urea denaturation. Glycine betaine and its precursor choline also restore the viability of a 
dnaK deletion mutant at $42{ }^{\circ} \mathrm{C}$. These results suggest that glycine betaine, in addition to its role as an osmoprotectant, is involved in the thermoprotection of bacteria.

\section{METHODS}

Bacterial strains. E. coli $\mathrm{K}-12$ strains C600 (leuB6 thr-1 thi-1 supE44) and 3000 (tsx-23 relA1 spoT1 thi-1) were used for glycine betaine and choline transport, respectively. The $d n a K$ deletion mutant GW4813 $\left(\Delta d n a K 52:: \mathrm{Cm}^{\mathrm{r}}\right)$ and its parental strain AB1157 (F thr-1ara-14 leuB6 $\Delta$ (gpt-proA)62 lacY1 ts $x$ 33 qsr supE44 galK21 rac hisG4 rfbD1 mgl-51 rpsL31 kdgK51 xyl-5 mtl-1 argE3 thi-1) were both tested for their colonyforming ability at 30 and $42{ }^{\circ} \mathrm{C}$.

Thermal aggregation of citrate synthase. The native enzyme $(80 \mu \mathrm{M})$ was diluted 100 -fold in $40 \mathrm{mM}$ HEPES, $50 \mathrm{mM} \mathrm{KCl}$, $10 \mathrm{mM}\left(\mathrm{NH}_{4}\right)_{2} \mathrm{SO}_{4}, 2 \mathrm{mM}$ potassium acetate, $\mathrm{pH} 8.0$ at $43{ }^{\circ} \mathrm{C}$ in the absence or in the presence of glycine betaine or choline. Citrate synthase aggregation was monitored by measuring the $A_{650}$ as described by Richarme \& Caldas (1997).

Thermal inactivation of citrate synthase and $\beta$-galactosidase. Citrate synthase was diluted to a final concentration of $80 \mathrm{nM}$ at $49^{\circ} \mathrm{C}$ in the absence or presence of glycine betaine or choline. Citrate synthase activity was determined as described by Richarme \& Caldas (1997). $\beta$-Galactosidase was diluted to a final concentration of $1.5 \mu \mathrm{M}$ at $56{ }^{\circ} \mathrm{C}$ in the absence or in the presence of glycine betaine. Its activity was determined by measuring the $A_{420}$ of samples containing $\beta$-galactosidase and $2.8 \mathrm{mM}$ ONPG in sodium phosphate buffer $\mathrm{pH} 7 \cdot 3$ at $25^{\circ} \mathrm{C}$.

Refolding of citrate synthase. Denaturation and renaturation reactions were carried out at $20^{\circ} \mathrm{C}$. Renaturation was initiated by pouring the renaturation solvent onto the unfolded protein, under vortex agitation, in Eppendorf polyethylene tubes. Citrate synthase was denatured at a concentration of $10 \mu \mathrm{M}$ in $8 \mathrm{M}$ urea, $50 \mathrm{mM}$ Tris/ $\mathrm{HCl}, 2 \mathrm{mM}$ EDTA, $20 \mathrm{mM}$ dithiothreitol, pH 8.0 for 50 min. Renaturation was initiated by a 100 -fold dilution in $40 \mathrm{mM}$ HEPES, $50 \mathrm{mM} \mathrm{KCl}, 10 \mathrm{mM}$ $\left(\mathrm{NH}_{4}\right)_{2} \mathrm{SO}_{4}, 2 \mathrm{mM}$ potassium acetate, $\mathrm{pH} \mathrm{8} 0$. The enzymic activity of citrate synthase was measured as described by Richarme \& Caldas (1997). DnaK was prepared as described by Richarme \& Caldas (1997).

Transport measurements. For glycine betaine (May et al., 1986) and choline uptake (Lanfald \& Strom, 1986), cells were grown in minimal medium M63 (Miller, 1972), supplemented with $0.4 \%$ glycerol or $0.4 \%$ glucose, respectively, as carbon source, and with the required amino acids added at $50 \mu \mathrm{g} \mathrm{ml}^{-1}$. Bacteria were harvested in the exponential phase of growth, washed once with the culture medium and diluted in the same medium supplemented with $300 \mathrm{mM} \mathrm{NaCl}$ to an $\mathrm{OD}_{600}$ of $0 \cdot 2$. The cell suspension was equilibrated at $22{ }^{\circ} \mathrm{C}$ for $10 \mathrm{~min}$, unless otherwise indicated. Transport was performed aerobically (200 r.p.m.), and was initiated by mixing $2 \mathrm{ml}$ cells with $\left[{ }^{14} \mathrm{C}\right]$ glycine betaine [synthesized as described by Ikuta et al. (1977), and used at $10 \mathrm{mCi} \mathrm{mmol}^{-1}\left(370 \mathrm{MBq} \mathrm{mmol}^{-1}\right)$ at the concentrations indicated in the text] or $\left[{ }^{3} \mathrm{H}\right]$ choline [obtained from Amersham, and used at $50 \mathrm{mCi} \mathrm{mmol}^{-1}$ $\left(1850 \mathrm{MBq} \mathrm{mmol}^{-1}\right)$, at the concentrations indicated in the text]. Samples $(200 \mu \mathrm{l})$ were removed, filtered through Millipore filters, washed with $3 \times 1 \mathrm{ml}$ transport medium and their radioactivity measured. To measure the effect of temperature shift-up on the rate of glycine betaine or choline uptake, exponential-phase cultures of E. coli were transferred from 30 to $42{ }^{\circ} \mathrm{C}$, and transport activities were measured at
$22{ }^{\circ} \mathrm{C}$ at several times before and after the temperature shiftup. Glycine betaine uptake was measured at $2 \mu \mathrm{M}$ glycine betaine, at which there is a major contribution of ProU, and at $200 \mu \mathrm{M}$ glycine betaine, at which both ProU and ProP are effective. Choline uptake was measured at $10 \mu \mathrm{M}$ and $200 \mu \mathrm{M}$ choline.

Colony-forming ability of the dnaK mutant. The colonyforming ability of the dnaK deletion strain GW4813 was studied by plating $100 \mu \mathrm{l}$ of a dilution of exponentially growing cells in M63 medium supplemented with $0.4 \%$ glucose, the required amino acids at $50 \mu \mathrm{g} \mathrm{ml}^{-1}$ and $1 \mathrm{mM}$ glycine betaine or choline, as indicated, containing 200 bacteria (assuming $6 \times 10^{8}$ bacteria $\mathrm{ml}^{-1}$ at $\mathrm{OD}_{600}=1$ : Stock et al., 1977), onto minimal medium agar plates (M63 medium supplemented with $0 \cdot 4 \%$ glucose, the required amino acids at $50 \mu \mathrm{g} \mathrm{ml}^{-1}$, and $1 \mathrm{mM}$ glycine betaine or choline, as indicated).

Materials. Citrate synthase (from porcine heart) was obtained from Sigma. All other chemicals were from Sigma and were reagent grade.

\section{RESULTS AND DISCUSSION}

\section{Glycine betaine and choline protect citrate synthase from irreversible aggregation during thermal stress}

We investigated the function of glycine betaine and choline under heat-shock conditions in vitro. Citrate synthase loses its native conformation and undergoes aggregation during incubation at $43{ }^{\circ} \mathrm{C}$ (Buchner et al., 1991; Richarme \& Caldas, 1997). Molecular chaperones (DnaK, GroEL and small heat-shock proteins) reduce or suppress citrate synthase aggregation (Buchner et al., 1991; Richarme \& Caldas, 1997). Low glycine betaine concentrations, around $50 \mathrm{mM}$ (as compared with the molar concentration attained after an osmotic upshock) efficiently reduced citrate synthase aggregation (Fig. 1). Higher glycine betaine concentrations completely suppressed citrate synthase aggregation (Fig. 1a). In similar conditions, the chaperone DnaK, at a concentration of $2 \mu \mathrm{M}$, completely suppresses citrate synthase aggregation (not shown, and Richarme \& Caldas, 1997). In similar conditions, choline, at concentrations between 50 and $200 \mu \mathrm{M}$, efficiently protected citrate synthase against thermal aggregation (Fig. 1b). Trehalose was much less efficient than glycine betaine and choline for the thermoprotection of citrate synthase, since concentrations lower than $300 \mathrm{mM}$ did not significantly affect aggregation (not shown).

\section{Glycine betaine and choline stabilize the enzymic activities of citrate synthase and $\beta$-galactosidase during thermal stress}

The velocity of citrate synthase inactivation at $49^{\circ} \mathrm{C}$ followed first-order kinetics, with $t_{1 / 2}$ ranging from $6 \mathrm{~min}$ in the absence of thermoprotectant, to $11 \mathrm{~min}$ in the presence of $300 \mathrm{mM}$ glycine betaine and $21 \mathrm{~min}$ in the presence of $300 \mathrm{mM}$ choline (Fig. 2a). We also tested the ability of glycine betaine to protect the activity of the E. coli $\beta$-galactosidase against thermodenaturation. As observed by Moses \& Sharp (1970), the thermal inactivation of $\beta$-galactosidase at $56^{\circ} \mathrm{C}$ followed 


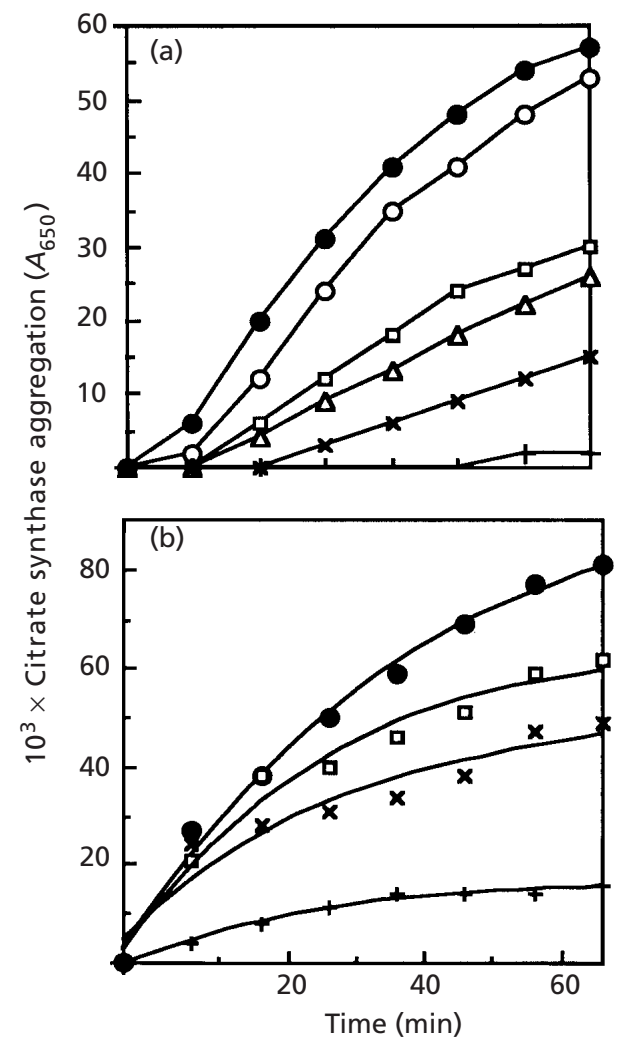

Fig. 1. Thermal aggregation of citrate synthase in the presence of glycine betaine or choline. The kinetics of citrate synthase aggregation was determined by light scattering at $650 \mathrm{~nm}$. Native citrate synthase was diluted to a final concentration of $0.8 \mu \mathrm{M}$ at $42{ }^{\circ} \mathrm{C}$, as described in Methods: (a) in the absence $(\bullet)$, or in the presence of $15 \mathrm{mM}(\bigcirc), 50 \mathrm{mM}(\square), 80 \mathrm{mM}(\triangle)$, $200 \mathrm{mM}(x)$ or $500 \mathrm{mM}(+)$ glycine betaine; (b) in the absence (๑) or in the presence of $50 \mathrm{mM}(\square), 200 \mathrm{mM}(x)$ or $500 \mathrm{mM}$ (+) choline.

biphasic kinetics. Both phases of thermodenaturation were protected by $300 \mathrm{mM}$ glycine betaine. The $t_{1 / 2}$ of the second phase rose from $3 \mathrm{~min}$ in the absence of glycine betaine to $7 \mathrm{~min}$ in its presence (Fig. 2b).

\section{Glycine betaine and choline increase the amount of correctly folded citrate synthase}

Since chaperones not only protect proteins against thermal stress, but also stimulate protein renaturation, we investigated whether glycine betaine and choline can stimulate the folding of proteins. Citrate synthase, whose refolding is facilitated by several chaperones such as GroEL, DnaK, Hsp90 and small heat-shock proteins (Buchner et al., 1991; Richarme \& Caldas, 1997), was chosen as substrate for this reaction. It was unfolded in the presence of $8 \mathrm{M}$ urea, and allowed to refold upon dilution of the denaturant, in the absence or presence of several glycine betaine or choline concentrations (citrate synthase refolding in the presence of DnaK was studied in parallel). Under our experimental conditions, the
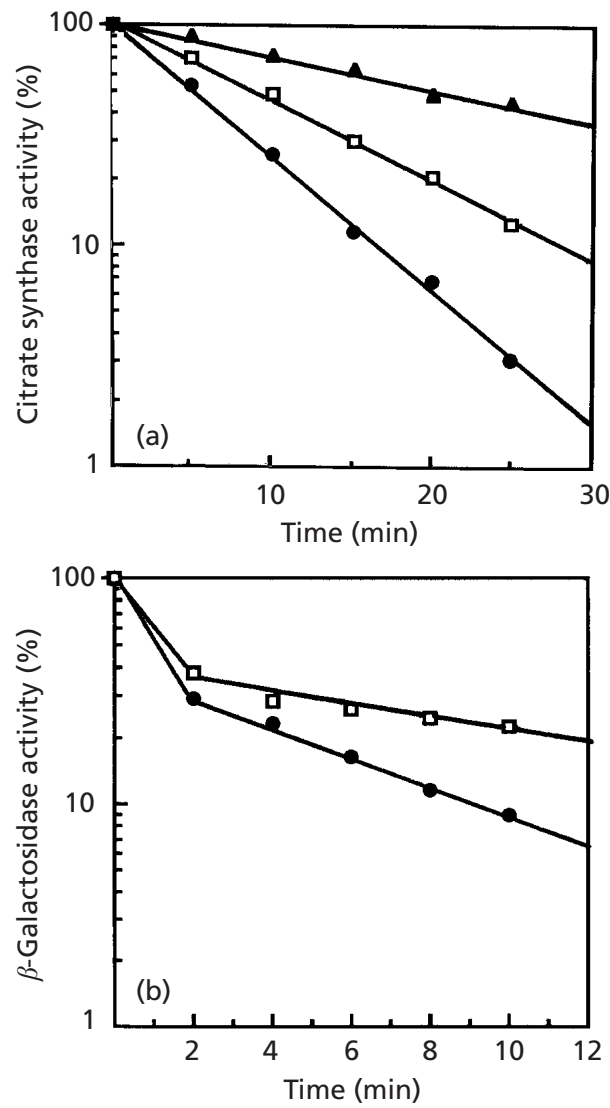

Fig. 2. Thermoprotection of citrate synthase and $\beta$ galactosidase activities by glycine betaine and choline. (a) Citrate synthase $(80 \mathrm{nM})$ was incubated at $49{ }^{\circ} \mathrm{C}$ in the absence (ब) or in the presence of $300 \mathrm{mM}$ glycine betaine ( $\square$ ) or choline (A). Samples were removed at intervals, cooled, and enzyme activity was subsequently determined at $25^{\circ} \mathrm{C}$ as described in Methods. (b) $\beta$-Galactosidase $(1.5 \mu \mathrm{M})$ was incubated at $56{ }^{\circ} \mathrm{C}$ in the absence (O) or the presence of $300 \mathrm{mM}$ glycine betaine $(\square)$. Samples were removed at intervals, cooled, and enzyme activity was subsequently determined at $25^{\circ} \mathrm{C}$ as described in Methods.

refolding yield of $0 \cdot 1 \mu \mathrm{M}$ citrate synthase was increased from $9 \%$ in the absence of thermoprotectant, to $17 \%$ in the presence of $100 \mathrm{mM}$ glycine betaine and $25 \%$ in the presence of $100 \mu \mathrm{M}$ choline (Fig. 3). In the presence of $300 \mathrm{mM}$ glycine betaine or choline, citrate synthase renaturation rose to $29 \%$ and $35 \%$, respectively. Thus, both glycine betaine and choline stimulate the renaturation of an unfolded protein. In similar conditions, the maximal renaturation of citrate synthase in the presence of DnaK was $33 \%$, and it was obtained in the presence of $3 \mu \mathrm{M}$ DnaK (not shown). The glycine betaine concentration which stimulates the reactivation of an unfolded protein can be easily attained in the bacterial cytoplasm in many physiological conditions, especially during stationary phase or osmotic stress, by accumulation of either glycine betaine or choline (Conska \& Epstein, 1996; Hengge-Aronis, 1996; Perroud \& Le Rudelier, 1985, Lanfald \& Strom, 1986). 


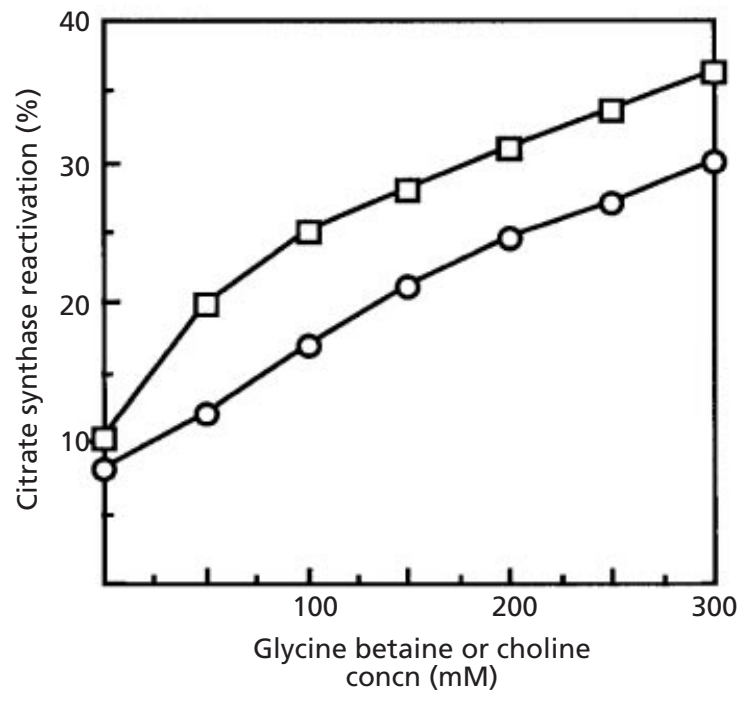

Fig. 3. Influence of glycine betaine or choline on the refolding of urea-denatured citrate synthase. Citrate synthase was denatured in urea and subsequently renatured for $20 \mathrm{~min}$ by dilution of the denaturant as described in Methods, at a concentration of $0.1 \mu \mathrm{M}$ in the presence of glycine betaine $(O)$ or choline $(\square)$ at the indicated concentrations.

\section{Glycine betaine and choline pools before and after heat shock}

A temperature shift-up did not significantly affect the rate of glycine betaine and choline uptake (transport activities were measured at $2 \mu \mathrm{M}$ or $200 \mu \mathrm{M}$ glycine betaine and 10 or $200 \mu \mathrm{M}$ choline, as described in Methods; not shown). This contrasts with the stimulation of glycine betaine uptake after a hyperosmotic upshock (Perroud \& Le Rudelier, 1985). In our experiments, the plateau of glycine betaine accumulation was obtained after $2.5 \mathrm{~h}$ (not shown), and corresponded to an internal glycine betaine concentration of $42 \mathrm{mM}$, assuming an internal volume of $3.5 \mu \mathrm{l}$ per mg cell protein (Perroud \& Le Rudelier, 1985; Stock et al., 1977). Similar glycine betaine pools were found when accumulation occurred at $30^{\circ} \mathrm{C}$ or $42^{\circ} \mathrm{C}$ (not shown). Similar glycine betaine pools (around $50 \mathrm{mM}$ ) were also observed at $30^{\circ} \mathrm{C}$ and $42{ }^{\circ} \mathrm{C}$, after the accumulation of $200 \mu \mathrm{M}$ choline (not shown) (it has been previously shown that choline is transported and quantitatively oxidized into glycine betaine by the Bet $\mathrm{T}$, BetA, BetB proteins: Lanfald \& Strom, 1986). Thus, although heat shock does not stimulate glycine betaine or choline accumulation, it does not reduce them either, and the internal glycine betaine concentration, independently of the heat shock procedure, attains $50 \mathrm{mM}$ in bacteria grown in usual minimal salts media in the presence of $200 \mu \mathrm{M}$ glycine betaine or choline. This concentration is in the same range as those which inhibit citrate synthase aggregation in vitro (see above). We also measured the glycine betaine pools of the dnaK deletion mutant described below, in the presence of $200 \mu \mathrm{M}$ glycine betaine or $200 \mu \mathrm{M}$ choline. We found intracellular
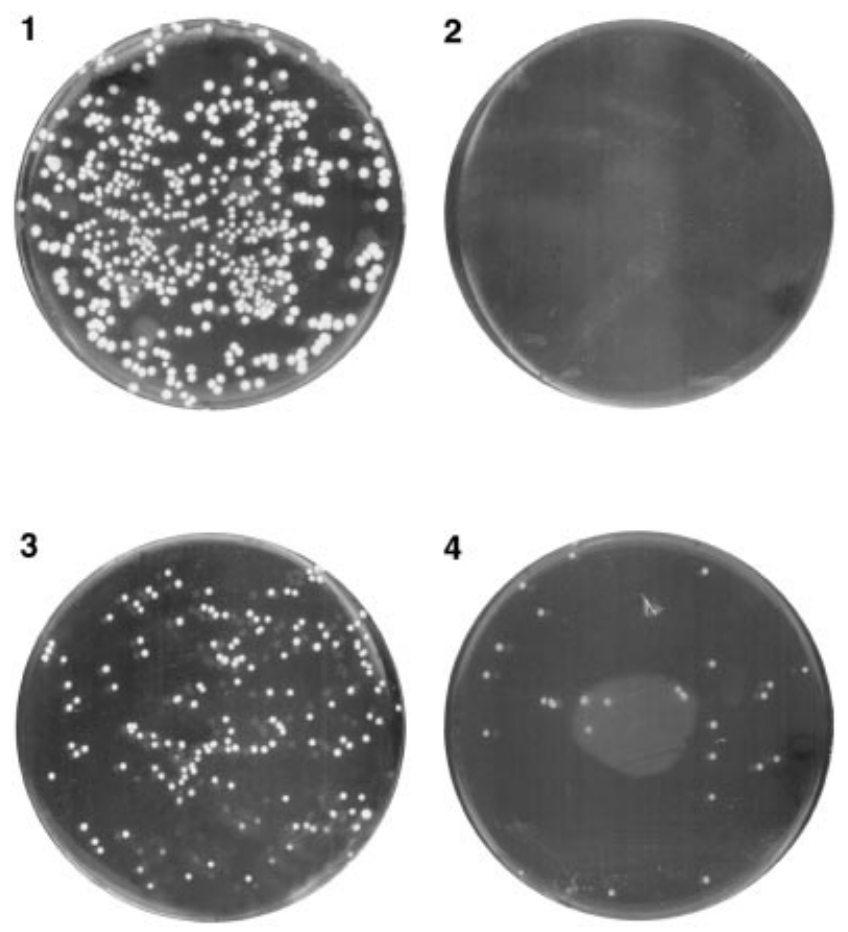

Fig. 4. Increase in the colony-forming ability of the dnaK deletion mutant at $42^{\circ} \mathrm{C}$ in the presence of choline or glycine betaine. The dnaK deletion mutant GW4813, grown at $30^{\circ} \mathrm{C}$ in minimal medium, was plated onto minimal medium agar plates at $30^{\circ} \mathrm{C}(1), 42{ }^{\circ} \mathrm{C}(2), 42{ }^{\circ} \mathrm{C}$ in the presence of $1 \mathrm{mM}$ choline (3), or $42^{\circ} \mathrm{C}$ in the presence of $1 \mathrm{mM}$ glycine betaine (4).

glycine betaine pools of $35 \mu \mathrm{M}$ and $58 \mu \mathrm{M}$, respectively, suggesting that this strain is not impaired in choline transport and metabolism. The higher glycine betaine pool obtained in the presence of external choline might explain the higher survival of the $d n a K$ strain at $42{ }^{\circ} \mathrm{C}$ in the presence of choline, as compared to its survival in the presence of glycine betaine (see below). However, the physiological state of bacteria in liquid medium is different from that of bacterial colonies on agar plates.

\section{Suppression of the thermosensitive phenotype of a dnaK deletion mutant by glycine betaine and choline}

The dnaK deletion mutant GW4813 is deficient for growth and viability at $42{ }^{\circ} \mathrm{C}$ (Paek \& Walker, 1987), probably as a consequence of protein aggregation. Samples $(100 \mu \mathrm{l})$ of a dilution of the $d n a K$ mutant were plated on M63-glucose agar plates, in the absence or presence of $1 \mathrm{mM}$ glycine betaine or choline, at 30 and $42{ }^{\circ} \mathrm{C}$. The colony-forming abilities of the dnaK mutant at 30 and $42{ }^{\circ} \mathrm{C}$ were compared. The colony-forming ability of the mutant at $42{ }^{\circ} \mathrm{C}$ rose from $0 \%$ (of that at $30{ }^{\circ} \mathrm{C}$ ) in the absence of additives, to $11 \%$ and $29 \%$ (mean value of three experiments) in the presence of $1 \mathrm{mM}$ glycine betaine and choline respectively (Fig. 4) (glycine betaine and choline had no effect on the colonyforming ability of the parental strain; not shown). Since choline is quantitatively metabolized into glycine 


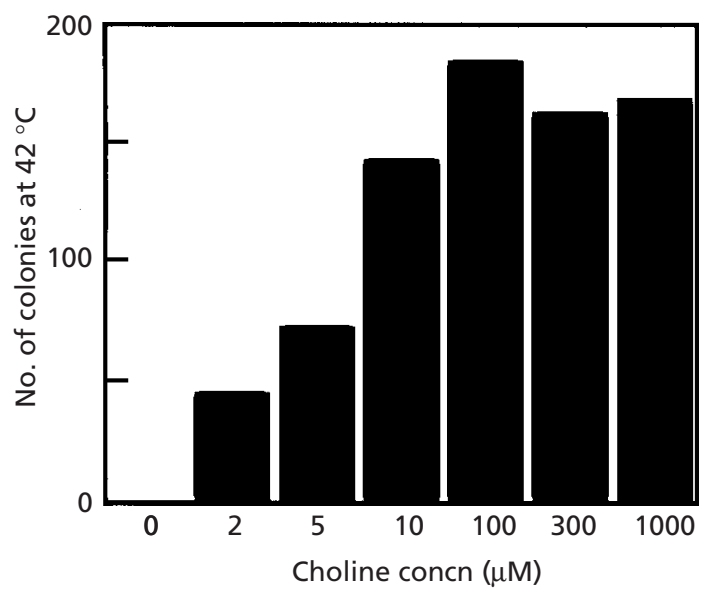

Fig. 5. Dependence on choline concentration of the colonyforming ability of the dnaK mutant. This experiment was done as described in the legend to Fig. 4, at different choline concentrations.

betaine in vivo (Lanfald \& Strom, 1986), we conclude that intracellular glycine betaine can partially compensate for the deficiency of the $d n a K$ mutant at $42{ }^{\circ} \mathrm{C}$, probably by reducing its known protein aggregation defect at elevated temperatures.

When bacteria were grown at $30^{\circ} \mathrm{C}$ in the presence of $1 \mathrm{mM}$ glycine betaine or choline, before plating at $42^{\circ} \mathrm{C}$ (in the presence of $1 \mathrm{mM}$ glycine betaine or choline), the colony-forming ability of the $d n a K$ deletion mutant rose to $29 \%$ and $42 \%$ respectively (data not shown).

We measured the dependence of the colony-forming ability of the $d n a K$ deletion mutant on the external concentrations of glycine betaine and choline (in the experimental conditions of Fig. 4). Half-maximal stimulation occurred at $2 \mu \mathrm{M}$ glycine betaine (not shown) and $6 \mu \mathrm{M}$ choline (Fig. 5). These concentrations are similar to the $K_{\mathrm{m}}$ of the ProU and BetT transport systems for glycine betaine and choline, respectively (May et al., 1986; Lamark et al., 1991; Boch et al., 1994).

We also checked whether incubation of the dnaK strain at $42{ }^{\circ} \mathrm{C}$ in liquid medium containing glycine betaine improves its survival at $30^{\circ} \mathrm{C}$ on agar plates without glycine betaine. The dnaK mutant was incubated for 90 min at $42{ }^{\circ} \mathrm{C}$, in minimal medium, in the absence or presence of $1 \mathrm{mM}$ glycine betaine. Bacteria were then washed with culture medium without glycine betaine, and subsequently plated on agar plates without glycine betaine at $30{ }^{\circ} \mathrm{C}$. The survival rate of the dnaK strain rose from $15 \%$ in the absence of glycine betaine to $55 \%$ in its presence, and the colonies were larger in the presence of glycine betaine (data not shown).

\section{Implications}

Our results suggest that glycine betaine and its precursor choline are involved in bacterial thermoprotection. In vitro, glycine betaine and choline protect citrate synthase against thermodenaturation and stimulate its renaturation, with an efficiency similar to that of protein chaperones, although at much higher concentrations. However, the glycine betaine concentrations which protect citrate synthase against thermodenaturation in vitro (around $50 \mathrm{mM}$ ) are similar to those found in bacteria grown in usual minimal media (this study). Although the protection of proteins by osmolytes in vitro often requires high concentrations of the latter (Yancey et al., 1982; Arakawa \& Timasheff, 1985), the protective effect of trimethylamine against the cold lability of phosphofructokinase shows a concentration threshold of around $50 \mathrm{mM}$ (Hand \& Somero, 1982), similar to that observed in our work. The amount of glycine betaine accumulated in our study $(48 \mathrm{nmol}$ per $\mathrm{mg}$ cell protein after $30 \mathrm{~min}$ ) is not significantly different from that obtained by others in similar conditions $(35 \mathrm{nmol}$ per $\mathrm{mg}$ cell protein after $30 \mathrm{~min}$ : Perroud \& Le Rudelier, 1985). The amounts of glycine betaine accumulated after an osmotic upshock and during the stationary phase are severalfold higher (Conska \& Epstein, 1996; Hengge-Aronis, 1996; Perroud \& Le Rudelier, 1985), and the thermoprotectant effect of glycine betaine should thus be even more effective in these physiological conditions. Although glycine betaine and choline are not synthesized endogenously, and have to be taken up from the external medium, they are often present in the natural environment of enterobacteria (Conska \& Epstein, 1996). Our results show that glycine betaine and choline partially restore the viability and growth deficiency of a dnaK deletion mutant at $42^{\circ} \mathrm{C}$. Suppressors of $d n a K$ null mutants that grow at $42{ }^{\circ} \mathrm{C}$ have been isolated (Paek \& Walker, 1987), suggesting that cells do not have an absolute requirement for the DnaK function for growth at $42{ }^{\circ} \mathrm{C}$. The present study shows that one of the socalled chemical chaperones (Talzelt et al., 1996), glycine betaine, can partially assume the function of the $d n a K$ gene product, and emphasizes the role played by small molecules such as polyols (Hengge-Aronis et al., 1991; Singer \& Lindquist, 1998; Yancey et al., 1982), trimethylamines (Talzelt et al., 1996; Yancey et al., 1982) and amino acids (Yancey et al., 1982) in the protection of cells against stress.

\section{ACKNOWLEDGEMENTS}

We thank Dr A. El Yaagoubi for his help during the early course of this work, Dr M. Kohiyama for constant support, Dr J. Meury for critical reading of the manuscript, and A. Kropfinger for correction of the English language. T.C. was supported by Fundaçao para a Ciência e Tecnologia of Portugal Grant PRAXIS/BD/13898/97. This work was supported by the 'Programme de Recherche Fondamentale en Microbiologie, Maladies Infectueuses et Parasitaires', Ministère de l'Education nationale, de la Recherche et de la Technologie.

\section{REFERENCES}

Arakawa, T. \& Timasheff, S. N. (1985). The protection of proteins by osmolytes. Biophys J 47, 411-414. 
Boch, J., Kempf, B. \& Bremer, E. (1994). Osmoregulation in Bacillus subtilis: synthesis of the osmoprotectant glycine betaine from exogenously provided choline. J Bacteriol 176, 5364-5371.

Buchner, J., Schmidt, M., Fuchs, M., Jaenicke, R., Rudolph, R., Schmid, F. \& Kiefhaber, T. (1991). GroE facilitates refolding of citrate synthase by suppressing aggregation. Biochemistry 30, 1586-1591.

Chambers, S. \& Cunin, C. M. (1985). The osmoprotective effect of betaine and human urine against low $\mathrm{pH}$ and high concentrations of electrolytes, sugars, and urea. J Infect Dis 152, 1308-1316.

Conska, L. N. \& Epstein, W. (1996). Osmoregulation. In Escherichia coli and Salmonella typhimurium: Cellular and Molecular Biology, pp. 1210-1223. Edited by F. C. Neidhardt and others. Washington, DC: American Society for Microbiology.

Georgopoulos, C., Liberek, K., Zylicz, M. \& Ang, D. (1994). Properties of the heat shock proteins of Escherichia coli and the autoregulation of the heat shock response. In The Biology of the Heat Shock Proteins and Molecular Chaperones, pp. 209-250. Edited by R. I. Morimoto, A. Tissieres \& C. Georgopoulos. Cold Spring Harbor, NY: Cold Spring Harbor Laboratory.

Gowrishankar, J. (1986). proP-mediated proline transport also plays a role in Escherichia coli osmoregulation. J Bacteriol 166, 331-333.

Hand, S. C. \& Somero, G. N. (1982). Urea and methylamine effects on rabbit muscle phosphofructokinase. J Biol Chem 257, 734-741.

Hendrick, J. P. \& Hartl, F. U. (1993). Molecular chaperone functions of heat shock proteins. Annu Rev Biochem 62, 349-384.

Hengge-Aronis, R. (1996). Regulation of gene expression during entry into stationary phase. In Escherichia coli and Salmonella typhimurium: Cellular and Molecular Biology, pp. 1497-1512. Edited by F. C. Neidhardt and others. Washington, DC: American Society for Microbiology.

Hengge-Aronis, R., Klein, W., Lange, R., Rimmele, M. \& Boos, W. (1991). Trehalose synthesis genes are controlled by the putative sigma factor encoded by $r p o S$ and are involved in stationary phase thermotolerance in Escherichia coli. J Bacteriol 173, 7918-7924.

Ikuta, S., Matuura, K., Imamura, S., Misaki, H. \& Horiuti, Y. (1977). Oxidative pathway of choline to betaine in the soluble fraction prepared from Arthrobacter globiformis. J Biochem 82, 157-163.

Lamark, T., Kaasen, I., Eshoo, M. W., Falkenberg, P., McDougall, J. \& Strom, A. R (1991). DNA sequence and analysis of the bet genes encoding the osmoregulatory choline-glycine betaine pathway of Escherichia coli. Mol Microbiol 5, 1049-1064.

Lanfald, B. \& Strom, A. R. (1986). Choline-glycine pathway confers a high level of osmotic tolerance in Escherichia coli. J Bacteriol 165, 849-855.

May, G., Faatz, E., Villarejo, M. \& Bremer, E. (1986). Binding protein dependent transport of glycine betaine and its osmotic regulation in Escherichia coli K12. Mol Gen Genet 205, 225-233.

Miller, J. H. (1972). Experiments in Molecular Genetics, p. 431. Cold Spring Harbor, NY: Cold Spring Harbor Laboratory.

Milner, J. L. S., Grothe, S. \& Wood, J. M. (1988). Proline porter II is activated by a hyperosmotic shift in both whole cells and membrane vesicles of Escherichia coli K-12. J Biol Chem 263, 14900-14905.

Moses, V. \& Sharp, P. B. (1970). Intermediates between metabolic intermediates and $\beta$-galactosidase of Escherichia coli. Biochem J 118, 491-495.

Paek, K.-H. \& Walker, G. C. (1987). Escherichia coli dnaK null mutants are inviable at high temperature. J Bacteriol 169, 283-290.

Perroud, B. \& Le Rudelier, D. (1985). Glycine betaine transport in Escherichia coli: osmotic modulation. J Bacteriol 161, 393-401.

Pollard, A. \& Wyn Jones, R. G. (1979). Metabolic engineering of glycine betaine synthesis. Planta 144, 291-298.

Richarme, G. \& Caldas, T. (1997). Chaperone properties of the bacterial periplasmic substrate-binding proteins. I Biol Chem 272, 15607-15612.

Singer, M. A. \& Lindquist, S. (1998). Multiple effects of trehalose on protein folding in vitro and in vivo. Mol Cell 1, 639-648.

Stirling, D. A., Hulton, C. S. J., Wadell, L., Park, S. F., Stuart, G. S. A. B., Booth, I. R. \& Higgins, C. F. (1989). Molecular characterization of the proU loci of Salmonella typhimurium and Escherichia coli encoding osmoregulated glycine betaine transport systems. Mol Microbiol 3, 1025-1038.

Stock, J. B., Rauch, B. \& Roseman, S. (1977). Periplasmic space in Salmonella typhimurium and Escherichia coli. J Biol Chem 252, 7850-7861.

Strom, A. R., Falkenberg, P. \& Landfald, B. (1986). Genetics of osmoregulation in Escherichia coli uptake and biosynthesis of organic osmolytes. FEMS Microbiol Rev 39, 79-86.

Talzelt, J., Prusiner, S. B. \& Welch, W. J. (1996). Chemical chaperones interfere with the formation of scrapie protein. EMBO J 15, 6363-6373.

Yancey, P. H. \& Somero, G. N. (1979). Counteraction of urea destabilization of protein structure by methylamine osmoregulatory compounds of elasmobranch fishes. Biochem J 183, 317-323.

Yancey, P. H., Clark, M. E., Hand, S. T., Bowlus, P. D. \& Somero, G. N. (1982). Living with water stress: evolution of osmolyte systems. Science 217, 1214-1222.

Received 21 December 1998; revised 28 April 1999; accepted 21 May 1999. 